\title{
CURRENT AFFAIRS PROGRAMMMES AS PUBLIC RELATIONS TOOL: A STUDY OF EBONYI BROADCASTING CORPORATION (EBBC), ABAKALIKI
}

\author{
Sunday Uche Aja, Ph.D \\ Department of Mass Communication \\ Alex Ekwueme Federal University Ndufu Alike, \\ PMB 1010, Abakaliki, Ebonyi State \\ ajauche@yahoo.com, aja.uche@ funai.edu.ng \\ $+2348060838661,08187010161$ \\ Joseph N. Chukwu, Ph.D \\ Department of Mass Communication \\ Alex Ekwueme Federal University, Ndufu Alike, \\ PMB 1010, Ebonyi State, Nigeria \\ chukwu.j3@gmail.com
Vincent Onyeaghanachi Odoh, Ph.D
Department of Mass Communication
Alex Ekwueme Federal University Ndufu Alike
PMB 1010, Abakaliki, Ebonyi State.
ifnotvin@yahoo.com

\begin{abstract}
The current affairs programmes of broadcast stations are considered as effective public relations tool. They bridge the gap between the government and the governed. They also attract goodwill and patronage for the station. This study focused on how effective current affairs programmes are used in Ebonyi Broadcasting Corporation (EBBC) to foist good image on the station. The survey method was used to get analyzable response from the station's audience. The study examined the potentials of current affairs as a broadcast programme and how it can be used as a tool of public relations. It specifically sought to determine if current affairs programmes have any effect on the relationship between the audience and any particular broadcast organization; identify the problems that affect the production of current affairs programmes as a public relations tool, and proffer solutions to ineffective current affairs programmes production. It further found out that good current affairs programmes affect station-audience relationship. This is not only because good current affairs programmes induce respect for, interest in and familiarity with the station, but they, more importantly, raise the popularity of the station. Thus these are invaluable resources which every organization craves for as they are also at the root of every good public relations campaign. The study, moreover, discovered that educated adults, mostly civil servants and business men and women listen to EBBC current affairs programmes regularly to know the activities in government (their chief employer and policy maker) and in the society at large. The study however found out that lack of requisite skills, lack of programme materials and lack of touch with station's environment and needs, and inadequate training of staff are chief among the problems affecting current affair programmes. It therefore recommended among others that broadcast establishments should be professional in their conduct to sustain and retain audience. These they can do by employing professionals in the field as well as carrying out regular training of staff to keep pace with the ever changing trend of audience appeal.
\end{abstract}

Keywords: Public Relations, Current Affairs, Broadcasting, EBBC, Nigeria

\section{INTRODUCTION}

Social complexities and sophistication regularly hunt the contemporary societies. The need for organizations and even governments to have good corporate image continues to be desirous. Organizations are no longer contented with carrying out their businesses just for profit maximization. They wish to be perceived as being socially responsible. Consequently, 
public relations departments have been created in many organizations for positive imagemaking and to create conducive environment for business.

The essence of public relations practice is rightly captured by Osuji $(1999, \mathrm{p} .4)$ when he defined Public Relations as:

\footnotetext{
... the process of creating a favourable public opinion for organizations, institutions, individuals, commodities or for intangible things such as names so that relevant members of the public who have something to do with these tangible or intangible things may perceive them in good way
}

The above conceptualization rather seems to be an elaboration of the one given by Public Relations Society of America (P.R.S.A). In 1988, the PRSA postulated that public relations help an organization and its publics adapt mutually to each other.

Public Relations is a broad-based practice. It is not optional in practice. It is neither seasonal, momentary nor a matter of chance activity. It is "a planned cyclic and interactive process, which involves actions, inactions and reactions from either the organization or the publics and their effects" (Nworgu, 2002 p.1). The practice of public relation assumes more importance considering the amount of time, money and effort that individuals and organizations spend in modern times to maintain relationships. This, perhaps, is why achieving mutuality of interest and gaining the support and cooperation of others through perception has been elevated an integral part of the day-to-day business of every organization (Okafor, 2002).

In broadcast organizations, current affairs programmes can be used as a public relations tool. Effective current affairs programmes can be utilized to create good relationship between organizations and their publics or between broadcast stations and their audiences, in a manner as to engender goodwill. Current affairs are broadcast programmes which involve a presentation of comments, opinions and analysis of current topical events and issues of public importance (NBC, 1996). Current affairs programme is one of the crucial responsibilities used by broadcast organizations to fulfill their information role to the society.

Current affairs programmes can help broadcast organizations reach their target audiences with timely information that can add tonic to their lives. The programmes can offer a platform for regular interactive session between an organization and its publics. Instead of waiting for a periodic press conferences or facility visits for an organization to communicate its policies and activities to its publics, a well planned daily current affairs programme can bridge the information gap, providing a timely social intercourse that helps to strengthen relationships and build reputation over time. This, of course, is the thrust of modern public relations.

Ebonyi Broadcasting Corporation (EBBC) 98.10 MHZ Frequency Modulation was established in 1997; following the creation of Ebonyi State along with five other States in Nigeria on October $1^{\text {st }}, 1996$. Earlier, the pioneer Military Administrator of Ebonyi State, Navy Captain Walter Feghabo had applied for both radio and television licenses to NBC on March $3^{\text {rd }}$, 1997. So, from inception, EBBC has been a government owned station. Dunu (2002, p.134) believes that:

As the bedrock and mainstay of broadcasting, programming involves a long term calculated, planned policy, expressed in predetermined executable action, which if appropriately implemented and executed as individual programme operations, wins maximum success for the stations. 
She concludes that if, alternatively, programming is done haphazardly, it will lead to loss of audience and the simultaneous loss in revenue generation. The losses can cause the death of the station.

It, therefore, becomes imperative to take a critical look at current affairs programmes, as a singular factor that can make or mar a broadcast organization. It is in an attempt to unravel the mysteries behind effective current affairs programmes and how they can be used as a public relations tool that has necessitated this study. It is believed that a well planned and structured research can help broadcast establishments to appreciate how important their current affairs programmes are, as a public relations tool.

\section{STATEMENT OF THE PROBLEM}

Some broadcast organizations seem to have lost prominence and their audience. They make little or no positive change in the society. Consequently, they neither attract patronage nor support. Advertisements and goodwill are scarce. Apart from government subvention, such broadcast organizations find it difficult to operate in the society. It becomes necessary to ascertain how broadcast stations can use their current affairs programmes to generate the goodwill that can guarantee their survival and profitability.

All the males and females who listen to the radio in Nigeria form the theoretical population of this study. It is this group that the study aims at generalizing its result to see how it appreciates current affairs programmes as a public relations tool used by broadcast stations. However, there is no single Nigerian radio station that can reach every male and female in Nigeria at the same time. The best achievable contact is the one made through programme networking by the Federal Radio Corporation of Nigeria (FRCN). The researchers, therefore, chose a practicable option - using a population that contains males and females, similar to what obtains in the Nigerian population. Thus, the listeners of EBBC in Abakaliki were purposively chosen as a case study in this study.

\section{OBJECTIVES OF THE STUDY}

This study generally examines the potentials of current affairs as a broadcast programme and how it can be used as a tool of public relations.

Specifically, this paper sought to:

$>$ Determine if current affairs programmes have any effect on the relationship between the audience and any particular broadcast organization.

$>$ Identify the problems that affect the production of current affairs programmes as a public relations tool.

$>$ Proffer solutions to ineffective current affairs programmes production.

\section{LITERATURE REVIEW}

\section{Producing Current Affairs Programmes (Need for Education and Training)}

Current affairs programmes are considered the means through which broadcast media provide an open market place of ideas for the citizenry. They, thus, guarantee the actualization of the "self righting process" - the bedrock of liberal democracy advocated by John Milton (16081674).

In their pioneering work on television and radio broadcasting, Chester, Garison and Willis (1978 p.60) had rightly explained that: 
Volume 1 Number 1 Maiden Issue

\begin{abstract}
current affairs programmes in a variety of forms provide information and understanding about the real world in which we live, they report information and news about activities as different as agricultural marketing and major league baseball contests, they present direct coverage of important events; they provide a public platform for speeches, press conferences and discussions of public issues; they dramatize through documentary techniques historical, events and current social and political problems; they provide a pulpit for religious services; they broadcast practical information for use in home making, shopping, family health and childbearing.
\end{abstract}

There is no doubt that it requires high talents to accomplish the task of producing current affairs programmes. Udeajah (2004 p.398), agrees that "training and retraining of staff are imperative not only for the growth of broadcast stations, but also for sharpening the professional input of the media organization”. He outlines such qualities as integrity, balance, fairness, objectivity and authenticity as the necessities for broadcasters in the discharge of their duties.

It has, however, been observed that some persons who go about as current affairs programmers in broadcast stations have either not received education in the field or are not adequately trained and equipped for the challenges of the job. Oso (2000) had noted this unfortunate situation in Nigeria and cautioned that it should not surprise us because journalism in Nigeria started more or less as a craft with the practitioners being trained on the job. A good number of pioneer journalists were printers and some others who failed in other endeavours.

Besides, it should be noted that current affairs programmes, most clearly, demonstrate the use of broadcasting to serve public interest. This becomes more evident given that no broadcasting system, however well intentioned, can survive without public acceptance (Chester et al, 1978).

It then presupposes that audience satisfaction should form the broadest base upon which every programme should be anchored. In essence, the knowledge of the component audience demography and psychography and their political and socio-economic realities, should constitute part of the intellectual foundation of the current affairs programmer, if audience satisfaction is to be properly addressed.

Unfortunately, audience appeal is a very unpredictable, ever changing phenomenon in social psychology. Chester et al, (1978 p.51) agree with this view and add that "programming deals with indefinable and intangible aspects of audience appeal". To this end, therefore, it requires extraordinary intellectual rigour and wisdom to grapple with the vagaries of producing current affairs programmes. In the words of the trio:

\footnotetext{
the best programming executives possess on uncanny ability to evaluate the indefinable and intangible aspects of audience appeal, a thorough knowledge of programme sources and show business in general, an acquaintance with programme cost that will enable them evaluate the risk involved in any programme venture and a high degree of boldness and courage (Chester et al, 1978 p.51).
}

This brings us to the question of what kind of education and training should current affairs programmers be exposed to. Is it a technical education that will acquaint them with the use of communication gadgets, or the one that will make them wizards in the use of language? Writing in this vein, Nduka (1998) notes that the educational system of any society is a more or less elaborate social mechanism designed to bring about, in the persons submitted to it, certain skills and attitude that are judged to be useful and desirable in the society. He argues 
that the end result of education is the production of an educated person who is expected to have mastered certain skills, to be cultured, and above all, to possess a trained mind.

In the context of this discourse, one can state that producing current affairs programmes needs cultured and educated minds. Such culture and education, as Oso (2000) puts it, must be that designed to take into consideration the socio-political make up of the country. This will enable programmers come up with current affairs that will directly address the problems in the Nigerian socio-political milieu.

There is also the need for a paradigm shift. This should include the principle of skepticism in current affairs programming. Skepticism, in this context entails a general intellectual outlook, - which does not deny assent but withholds it until justification is given. This virtue becomes important considering the fact that broadcast system of Nigeria tends to encourage downward communication more than it does the upward (Udeajah, 2004). The adoption of skeptical stance in programming will dismantle the elitist structure of broadcasting in Nigeria. It will also free the broadcast media from the supremacist and racist prejudices of the nouveauriches. And out of the fountain of neutrality and freedom, public acceptance, goodwill patronage flow.

Indeed, if we agree with MacBride et al, (1981 p.230) that "the quality of any system is largely governed by the calibre of those who operate it", and if we want to churn out effective current affairs programmes, those that can meet the appeals of the station's audience and win their acceptance, then, comprehensive education and training should be vigorously pursued. This education programme must go beyond teaching techniques and skills to exploring intellectual and academic issues. This element should form an integral part of the new paradigm, to replace the old on-the-job training system, which has ended up training more craftsmen than cultured and educated minds (Oso, 2000 p.35). We need not reiterate that this new education calls for new tools, new understanding and new orientation on the part of media owners. By this way, broadcast establishments can be rest assured of resourceful current affairs programmers whose performance will win patronage and goodwill for their station.

\section{TOWARDS EFFECTIVE BROADCAST CURRENT AFFAIRS PROGRAMMING}

The problem of ineffective current affairs programming seems to arise basically from lack of knowledge about the specified audience, the potentials of broadcast media, communication theory and the objectives of broadcasting in the first instance. These basic deficiencies tend to limit the power of broadcasting to educate, inform and entertain the audience.

The audience should not be regarded as people who will be fed with anything the media choose. The media have many audiences some of which are outlined below.

Audiences are Targeted: Audience is targeted by advertising managers of broadcast stations. There is an audience for radio programme such as soap opera. There is an audience for magazine on world soccer. All these audiences have slightly different characteristics, which is measured by the usual markers of age, gender, etc. Audience with such characteristics can be targeted by producing materials, which appeals to them. This raises an interesting question as to whether the audience is found or made. Does a programmer have an audience in mind before putting up material to suit it? Or is the material put on, which then finds an audience? Obviously, after many years, both producers of radio and journalists have a fair idea of what 
their audience is like and what they want. But still, it brings one to another point as indicated below.

Audience may be constructed: This idea points to the fact that it is possible to find an audience for a media product and built it up. For instance, some electronic media like AIT, Channels TV, etc surfaced and built their audience. So did our indigenous film industries. Audiences are crucial factors in modeling the communication process in the media.

Audiences are active: With the high level of literacy in the society, audiences have become more and more active and sophisticated. This means that audiences actively select what they want to listen to or watch.

The broadcast media are associated with four major human attribute. They include "immediacy, spontaneity, topicality and versatility" (Obasi, 2004 p.3). Every successful current affairs programme demands that these characteristics be clearly known and mastered so that they can be capitalized upon during production. The broad objectives of broadcasting include education, information and entertainment. The agenda for educational broadcasting includes technical communication (skill acquisition), general cognitive communication (knowledge) and normative communication (accepted standard of behaviour) (Obasi, 2004 p.4).

We transmit various kinds of technical communication to enable the public orientate themselves to their environment. Knowledge in various areas of human endeavour is transmitted through general cognitive communication, while information designed to uphold various social norms and to define proper behaviour in various roles and situation is transmitted through normative communication.

Anyone planning a current affairs programme must therefore, take cognizance of these agenda. It will be a waste of time producing a programme, which does not reflect these important communication agenda. There is, therefore, the need to effectively plan programme production and presentation.

In her treatise on programming, Dunu (2002) remarks that programming as a feature of broadcasting has basic factors, which include research, planning, materials, execution and evaluation. These factors combine in a synergistic manner to produce an effective current affairs programme. And programming occurs in three phases. Namely:

- Programme selection (Research): Research as the first stage is conducted to gather facts that will go into the programme. Kogar (1999 p.42) affirms that a writer of documentary, for instance, "cannot escape research responsibility for he must immerse himself sufficiently in the subject to develop a point of view and determine what he wants to know".

- Programme Scheduling: This has to do with the organization and packaging of preselected programme materials into a coherent programme service for a broadcast period. Appropriate timing and placement of programme types at designated duration has been identified as essential factor which can alleviate the problem of a station's image and achieve acceptability.

- Programme evaluation: This involves the assessment of a particular programme's effort. Each programme is evaluated based on the extent to which its content reflect current social trends and meets the needs of the audience. 
Volume 1 Number 1 Maiden Issue

The truth is that without good planning, research, materials, execution, and evaluation, effective current affairs programmes will continue to elude many broadcast organizations. Effective current affairs programming goes further to include skillful selection and management of programme materials that must appeal to and satisfy audience need for information and entertainment. It involves consistent placement that will always suit audience time and activity. The satisfaction of the audience is the secret for effective current affairs programming.

\title{
Importance of Current Affairs Programmes to the Audience
}

\author{
...by giving voice and visibility to all - including and especially the poor, the marginalized and members \\ of minorities - the media can help remedy the inequalities, the corruption, the ethnic tensions and \\ human rights abuses that form the root causes of so many conflicts. \\ - Kofi Anan, former UN Secretary General.
}

The above statement by the erstwhile United Nation's Chief Scribe aptly describes the value of current affairs programmes to the audience. It gives voice to the voiceless through vox pops, phone-in programmes, etc.

Another point of excellence of current affairs to the audience is in the area of providing one major media function - interpretation - to the illiterate rural dwellers. This section of humanity, on account of their illiteracy, may not be able to read newspapers, where such interpretative stories are normally contained. Where they can, they are plagued either by lack of rural community newspapers or are so downtrodden and poverty-stricken that they cannot afford the copy price of a newspaper. Dominic (1996 p.38) agrees that "the mass media (nay broadcasting) do not supply just facts and data. They also provide information on the ultimate meaning and significance of those events". Talk progammes, documentaries produced in local languages serve this purpose.

Akin to the above, current affairs has the potential to raise the political consciousness of the populace. A live coverage of political news conference keeps the citizens alert on the political activities in the country. It also educates them on their rights as provided in the constitution. Indeed, broadcasting (nay current affairs) and politics in Nigeria have been likened to Siamese twins. Any surgical operation aimed at separation that is not carefully carried out could lead to death of either, if not, both (Udeajah, 2004).

Broadcast current affairs programmes also provide a forum for open discussion of current issues of public importance. Regarding this essential role, Nwosu (1993 p.31) affirms that:

\footnotetext{
...with the growth and demands of society in the political and socio-economic sectors, with the complexities and individual differences becoming sharper and more controversial, with various factors affecting the day-to-day life of citizens, it became necessary to discuss, to criticize and to air one's view. This concept of free debate ... often occurs in the media (in current affairs)
}

The audience equally needs timely and continuous flow of current information in their daily lives. The analysis of the information is no less important. Neither is hearing the news makers in actuality inefficiency in job performance. "There will always be a need for news from reliable and knowledgeable sources" MacBride et al (1981 p.200). Current affairs programmes provide the audience with these services as tonic to refresh their lives. 


\section{IMPORTANCE OF CURRENT AFFAIRS PROGRAMMES TO THE GOVERNMENT}

Broadcast current affairs programmes, no doubt, are essential to the dissemination of information on government policies and activities. It also affords government the opportunity of a feedback from the populace. Onabanjo (2000 p.51) rightly observes that:

Policies are formulated on continuous bases that have a bearing on the hopes and aspirations of the citizenry. These policies have to be properly examined, scrutinized and debated on as a means of feeding back the policy makers on the viability or otherwise of such policies

The above statement underscores the necessity of an open discussion forum to which government policies can be subjected for acid test for their viability or otherwise. Current affairs, by its nature, represent this discussion forum.

It has also been observed that broadcast current affairs programmes affects government decision-making process and policies. This is because, current affairs has, as its thrust, the aggregation, sharpening and expression of the opinions and reactions of the audience towards the always-newsworthy actions of government.

Writing on "the effects of mass media (nay current affairs) on government," Ebeze (2002 p.284), drawing heavily from Nwosu (1993), listed the following:

- Defining and Redefining Government Policies and Laws: This precisely means understanding government policies, giving them contemporary interpretation, relating them also to the culture and developmental expectations of the society, to what government has stated as its goal and objectives and finally assessing and clarifying them for better understanding by the masses.

- Creating change or shift: The mass media's objective is to create change for the better. That change or shift could be radical or gradual. In its entertainment, cultural, educative and information functions, the objective is to introduce new ideas or to extol old ones, which are then consumed by the target audience. Thus, the mass media (current affairs) affect the government through these novel ideas, persuade it to consider them and probably adapt them.

- Entrenching or Retrenching Government: This is now commonplace in Nigerian polity. The power of the media, its persuasiveness and pervasiveness has bestowed upon it that rare power to influence. Think of Gowon's regime. It surely was a victim of mass media criticisms. What of Shagari era? No doubt, it fell in the face of mass media assault. There are a host of other examples, in spite of chequered history of press freedom in Nigeria.

- Building a More Aware Leadership: The media have taken on the task of acting as forum for discourse and debate where knowledge, information and intelligence are transferred to their audience. The leaders in government, while listening to electronic media, are made aware of the educational, political social on-goings within their sphere of influence. Through such criticisms of its failures and successes, the government adjusts' where it deems fit.

\section{THEORETICAL FRAMEWORK}

Public Relations is essentially a sub-field of mass communication. As such, it benefits from the wealth of the theoretical approaches to the study of mass communication. Therefore, it is common to see such theories of mass communication as uses and gratification, agenda 
setting, framing, etc, being applied to provide theoretical underpinnings for public relations practice. However, because, building relationships is at the root of public relations practice, theories of relationships have also assumed significance to the understanding of public relations both as a profession and field of study. One relationship theory that guided this work is system theory.

System Theory: This theory is generally regarded as science of wholeness. The theory looks at organizations as systems which have interacting elements that are open to, and interact with their environment. Organizations are assumed to be made up of interrelated parts that adapt and adjust to changes in the socio-political and economic environment in which they operate. System theory was proposed by the biologist, Ludwid von Bertalanffy in 1940's and later formalized by Ross Ashby (1964).

Rather than acting as isolated distinct and independent entity, system theory would have us believe that organizations are part of greater environment made up of many parts, which depend on each other for survival. The theory emphasizes the interdependence of organizations with their environments, both internal and external to the organization. According to the theory, there must be a communication structure which the leaders of the organization must create to guide the parts of the organization to achieve organizational goals.

System theory is relevant to this study for obvious reasons. The postulations of this theory offer explanations to suggest that the broadcast organizations in Nigeria and their audience (their environment) are interdependent. The broadcast outfits depend on the audience for listenership, viewership and patronage in order to survive. The audience depends on the broadcast stations for information, education and entertainment. Hence, this study tried to examine current affairs programmes as the communication structure and how effectively they have been employed by broadcast organizations to create good relationship with audience for survival and prosperity.

Uses and Gratification Theory: This paper is also modeled in line with uses and gratification theory of mass communication. This theory assumes that individuals play an active role in the process of communication and are goal-oriented in their media behavior. The theory represents one of the major theories in the minimalist media effect paradigm, which aptly describes the nature of audience media preference in this contemporary time. Elihu Katz and Jay Blumler were among the foremost researchers to conceptualise this theory in their work published in 1974. The theory focuses on how audience members use media sources to satisfy their needs and desires. Such needs or desires include cognitive and affective needs, involving personal and entertainment needs (Dominick, 1996).

Uses and Gratification perspective lends itself fully to this work, as its tenets express the same paradigm with the thrust of this study, namely: that audience preference of a particular current affairs programme is quite purposeful and deliberate, not random. Rather than assuming that media messages will have direct uniform effects on those who consume them, uses and gratification theory would have us believe that audience members make deliberate intentional decisions about the media and message they expose themselves to and what frequency based on personal needs and desires. The audience of broadcast current affairs programmes cannot be understood in its traditionally holistic nature as a mass audience whose behaviour or reaction to media messages can be taken for granted or naively predicted. 
Volume 1 Number 1 Maiden Issue

They are now active and "express judgment by tuning in and out of programmes" (Chester et al, 1978 p.103). Hence, this study strives to find out what motivates audience to listen to or watch a particular broadcast current affairs programme.

\section{METHODOLOGY}

The study employed survey research design. The population of the study was 32,909 residents of Abakaliki capital city. This was the projected population figure by the National Population Commission cited in National Bureau of Statistics Report 2019. The residents of Abakaliki metropolis were purposively chosen because they are the nearest audience to be reached by the programmes of EBBC due to their location in Abakaliki where the station is also located. The sample size for the study was 300. According to Wimmer and Dominick $(2011$, p.103) “ $\ldots 50=$ very poor, $100=$ poor, $200=$ fair, $300=$ good, $500=$ very good and $1000=$ excellent."

A multi-stage sampling technique was used, as this is a multivariate study. This technique involved the researchers getting to the respondents through different stages of sampling. In the first stage, the area of study was divided into six (6) zones, following the geopolitical zones of the Federal Republic of Nigeria. The zones were: Isieke, Azugwu, Presco, Sam-Egwu Way, Afikpo Road and Onueke. In the second stage, the stratified sampling technique was used to ensure adequate representation of every member of the population. The population figure obtained for each zone from the National Population Commission's office in Abakaliki, enabled the selection of the sample from the zones in a stratified manner. The detail is as shown below:

$\begin{array}{cccc}\text { SN } & \text { Zone } & \text { Population } & \text { Sample } \\ 1 & \text { Isieke } & 5,110 & 50 \\ 2 & \text { Azugwu } & 5,500 & 50 \\ 3 & \text { Presco } & 6,020 & 50 \\ 4 & \text { Sam-Egwu Way } & 5,905 & 50 \\ 5 & \text { Afikpo Road } & 5,112 & 50 \\ 6 & \text { Onueke } & 5,202 & 50 \\ & \text { Total } & \mathbf{3 2 , 9 0 9} & \mathbf{3 0 0}\end{array}$

Source: NPC official records in Abakaliki, 2019.

Finally, the research instrument was administered to the respondents in the zones using the simple random sampling technique.

Questionnaire served as instrument for data collection. The questionnaire was face-validated by two experts in the field of Mass Communication, who tested its content for clarity, variability and accuracy. The experts ensured that the responses, generated through the questionnaire, were original and impossible to trace with external criteria like behavioural realities and official records. To ensure reliability, test-re-test approach was used. Twenty (20) copies of the questionnaire were used in the test-re-test reliability study which gave a coefficient of 0.8. Data generated were presented using simple frequency distribution tables and percentages. Graphs and charts were used where necessary to enhance clarity. 


\section{FINDINGS}

Table 1: Nature of Relationship between Current Affairs Programme Production and Audience

Question

How does a good current affairs programme affect your relationship with the station?

Total

Source: Field Survey, 2019
Responses

Familiarity with the

programme

Interest in the programme

Popularity of the station

Respect for the station

$\begin{array}{cc}\text { Respondents } & \text { Percentage } \\ 78 & 26 \% \\ & \\ 63 & 21 \% \\ 102 & 34 \% \\ 57 & 19 \% \\ 300 & 100 \%\end{array}$

Table 2: Nature of Problems of Effective Current Affairs Programming

Question

What can be responsible for poor quality current affairs programming?

Total

Source: Field Survey, 2019
Responses

Inadequate training

Incompetence

Lack of programme material

Lack of touch with the

station's audience

$\begin{array}{cc}\text { Respondents } & \text { Percentage } \\ 102 & 34 \% \\ 78 & 26 \% \\ 51 & 17 \% \\ 69 & 23 \% \\ & \\ 300 & 100 \%\end{array}$

Table 3: Solutions to Problems of Effective Current Affairs Programming

Question

What is the solution to ineffective current affairs programming?

\section{Total}

\section{Responses}

Correct observed problems

Train programme producers

appropriately

Remove programmers

$\begin{array}{cc}\text { Respondents } & \text { Percentage } \\ 84 & 28 \% \\ 162 & 54 \% \\ & \\ 54 & 18 \% \\ 300 & 100 \%\end{array}$

Source: Field Survey, 2019

\section{Summary of Findings}

The following are the summary of findings made in this study:

$>$ Much importance is attached to current affairs programmes by the Nigerian broadcast audience.

$>$ More Nigerian educated adult civil servants and businessmen/women listen to current affairs programmes than any other classes of people.

$>$ Quality of production and regular audience participation are the major factors that attract Nigerian audience to current affairs programmes.

$>$ There is a relationship between an audience and broadcast stations.

$>$ Such relationship can attract goodwill and patronage to the broadcast organization.

$>$ The effectiveness of current affairs programmes affects such relationship positively by raising the popularity of the station among other benefits.

$>$ At present, there is predominantly an ineffective current affairs programming in most Nigerian broadcast establishments.

$>$ Inadequate training is the major cause of poor quality current affairs programming in Nigeria.

$>$ Such poor quality current affairs programming can be improved by training programme producers appropriately. 
$>$ Current affairs is a public relations tool.

\section{DISCUSSION OF FINDINGS}

It is discovered that the educated adults listen to EBBC current affairs programmes regularly. The research also shows that majority of the listeners are civil servants and businessmen and women who probably wish to know the activities in government (their chief employer and policy maker) and in the society at large. This implies that EEBC current affairs programmes have a specialized audience. And as observed by Dominick (1996, p.479), specialized audience is "typified by fragmented special interest audience groups. Media content is designed to appeal to distinct and particular audience segment."

The study also discovers that there is a significant relationship between audience groups and EEBC. The relationship is tied, among other factors, mainly on the quality of current affairs programmes production and regular audience participation. An active and pluralistic audience of this nature is found in democratic societies like the one existing in Nigeria currently. The media in this kind of society are also viewed as adding to the series of sources of power which are said to prevent disproportionate degree of power from being concentrated in the hands of any one section of the population or organ of government (Akpan, 2004). Against this backdrop, this finding reinforces the postulations of the uses and gratification theory, affirming that audience groups expose themselves deliberately and selectively to broadcast current affairs with the intention to satisfy their needs.

Good current affairs programmes are identified by the findings as affecting station-audience relationship. This is because they are part of the audience expectation from broadcast establishments. The findings also show that good current affairs programmes not only induce respect for, interest in and familiarity with the station, but they more importantly raise the popularity of the station. These are invaluable resources which every organization craves for. They are also the aim of every good public relations campaign. After all, public relations has been identified as nothing other than the planned effort to influence opinion through good character and responsible performance, based upon mutually satisfactory two-way communication (Cutlip \&Centre, 1978). Therefore, this finding provides empirical evidence in support that current affairs is public relations tool.

We also tried to examine the nature of the problems militating against effective use of current affairs to foist good image for broadcast stations. While indicting a number of factors, including lack of requisite skills, lack of programme materials and lack of touch with station's environment and needs, the findings specifically identify inadequate training of staff as chief among the problems. This finding is consistent with the position of Okafor (2002) who decried this unfortunate situation and cautioned that "without the right people ... vital management process can become inefficient", (p.58).

Interestingly, the findings reveal that appropriate training of programme producers will be the magic wand that will end the scourge of poor current affairs programming in broadcast organizations. Training of staff becomes more critical as contemporary thinking about public relations has elevated it as a responsibility of all the employees, ranging from the gate man to highest officer. Those employed by an organization are the organization [itself] because, the public judges the organization with the people associated with it. This presupposes that the engagement of trained employees will help broadcast establishments grapple with their image problems. 


\section{CONCLUSION}

It is discovered that current affairs has a specialized audience in Nigeria. This specialized audience (educated civil servants and businessmen/women) constitute the substantial segment of the society. As such, they are likely to be the fountain from where patronage flows to the station.

The relationship existing between a broadcast establishment and its audience is capable of attracting patronage in the form of advertisements and goodwill. This will, in the long run, uplift the image of the station.

However, poor current affairs programming, as the study shows, hampers the achievement of healthy relationship between broadcast stations and their audiences in Nigeria. This is because, as discovered in this study, effective current affairs, while analyzing the topical issues of public importance, works to raise the popularity and good image of the station. The achievement of popularity and good image between organizations and their various publics through good performance is the main thrust of modern public relations.

According to the research findings, training and re-training of programme producers is a significant way to sustain quality in production and popularity. It also builds acceptance, goodwill and patronage to the station. Current affairs, in this way, is an effective public relations tool.

\section{RECOMMENDATIONS}

- Broadcast establishments should realize that maintaining good image is not only a function of singing one's praises. Communication should be matched with responsible performance for public interest. Little wonder to some, public relations is "doing good and getting credit for it". Others prefer to call it "good performance publicly appreciated and communicated".

- Current affairs programmes production should be given the right attention it deserves, especially in a democratic society like Nigeria where the mass media are expected to function effectively to serve society. They constitute an important broadcast package that gives the audience the opportunity of participation in broadcast messages.

- Broadcast organizations should ensure that they employ graduates of mass communication or journalism. These trained personnel will bring professional touch into programme production. Training and retraining of staff periodically should be embarked upon, to keep pace with the ever changing trend of audience appeal.

- Producers of current affairs programmes should ensure constant touch with their stations' environment. This will enable their produced programmes to satisfy the needs and aspirations of the audience. It will also make the discussed issues resourceful and relevant to the audience. It will make the current affairs more effective as a public relations tool.

\section{REFERENCES}

Akpan, I. (2004). Marketing foundation of advertising and public relations. Unpublished Lecture Notes, Abia State University.

Akpan, I. (2004). Media and society. Unpublished Lecture Notes.Abia State University, Uturu. 
Ashby, R. W. (1964). Introduction to cybernetics. London: Routledge Kegan \& Paul.

Chester, G., Garrison, G.R., Willis, E.E. (1978).Television and radio (5th Edition). New Jersey: Prentice Hall.

Cutlip, S.\& Center, A. (1978).Effective public relations. New Jersey: Prentice Hall.

Dominick, J.R. (1996). The dynamics of mass communication. $\left(5^{\text {th }}\right.$ edition). New York: The McGraw-Hill Companies, Inc.

Dunu, I. V. (2002). Broadcasting programming strategies. In Okunna (ed). Teaching mass communication: A multi-dimensionalapproach. Enugu: New Generation Books.

Ebeze, U.V. (2002). Media and Society. .In Okunna (ed). Teaching mass communication: A multi-dimensional approach. Enugu: New Generation Books.

Kogah, V.C. (1999). Visual communication: Films, graphics photo journalism. Owerri: Gust Chucks Graphic Centre.

Konkwo, P.D.E. (2003). Principles, concepts, theories and practice of mass communication. $\left(2^{\text {nd }}\right.$ Edition). Owerri: Concave Publications.

MacBride, S. et al. (1981).Many voices, one world. lbadan: University of Ibadan Press.

Mboho, M. (2004). Introduction to communication research. Unpublished Lecture Notes. Abia State University, Uturu.

NBC (1996). The National Broadcasting Code. Lagos: National Broadcasting Commission (NBC).

Nduka, O. (1998). The essence and value of education. In Badmus \& Osiyale (eds): Private and Community Participation in Education in Nigeria. Lagos: Nigerian Academy of Education.

Nworgu, K. O. (2002). Public relations (Special issues and topics) Volume One. Enugu: Ultimate Books.

Nwosu, I. (1993). Mass Media and the Nigerian Society. Nnewi: The Readers Choice press.

Obasi, N. (2004). Television programme writing and production. Unpublished Lecture Notes. Abia State University, Uturu.

Okafor, G.O. (2002). Principles of public relations. In Okunna (ed).Teaching Mass Communication: A multi-dimensional Approach. Enugu: New Generation Books.

Onabanjo, O. (2000).Broadcast Management and Programming. Lagos: Gabi Concept Ltd. 
Oso, L, (2000). Inculcating ethical standards through education. In Arogundade (ed.) Ethics and Regulation: Formulating a Working Agenda for Journalists. MFD/IFJ Ibadan Seminar July 26-28, 2000.

Osuji, C. (1999). Dynamics of Public Relations (Theoretical and functional framework). Owerri: Opinion Research \& Communications Inc.

Udeajah, R.A. (2004). Broadcasting and Politics in Nigeria (1963-2003).Enugu: Snaap Press Ltd.

Wimmer, R. D. \& Dominick, J. R. (2000). Mass Media Research. An Introduction. ( $6^{\text {th }}$ edition). California: Wadsworth. 